\title{
Cell Phones and Male Infertility: A Review of Recent Innovations in Technology and Consequences
}

\author{
Ashok Agarwal, Aspinder Singh, Alaa Hamada, Kavindra Kesari \\ Center for Reproductive Medicine, Cleveland Clinic, Cleveland, Ohio, United States
}

\begin{abstract}
Cell phones have become a vital part of everyday life. However, the health risks associated with their usage are often overlooked. Recently, evidence from several studies supports a growing claim that cell phone usage may have a detrimental effect on sperm parameters leading to decreased male fertility. Nonetheless, other studies showed no conclusive link between male infertility and cell phone usage. The ambiguity of such results is attributed to the lack of a centralized assay for measuring inflicted damage caused by cell phones. Study design, ethics, and reproducibility are all aspects which must be standardized before any conclusions can be made.
\end{abstract}

Key words: male; infertility; spermatozoa; cellular phone; radiation

Int Braz J Urol. 2011; 37: 432-454

\section{INTRODUCTION}

In today's society, modern man strives to become increasingly efficient. Our fast pace lives have been the driving forces behind vast technological innovations such as the Internet, email, and most recently, the "Smartphone". Cell phones have become a vital part of our lives, and as the social pressures for optimal efficiency increase, so do the technological capabilities of cell phones.

One, often overlooked, aspect associated with recent innovations in cell phone technology, is the impact of these devices on human health, more specifically male fertility. Recent innovations in cell phone technology may have a detrimental effect on male fertility, and maybe a growing factor contributing to male infertility. This article will focus on cell phones and dissect exactly what the recent innovations in technology mean for human reproductive health and male fertility.
The essential topics of this article comprise a basic description of the cell phone technology and pathophysiological effects of the emitted radiation from cell phone devices on testicular tissues and sperm function. In addition, analysis of emerging clues from laboratory and human studies will be discussed taking into account the controversy surrounding cell phone research. Lastly, a comprehensive future look into the ensuing fertility consequences related to cell phone technology will be discussed.

\section{General concepts of cell phone physics and bio- logical effects \\ Cell phones emit radiofrequency electro- magnetic waves (RF-EMW) to nearby relay base stations or antennas. Our bodies act as antennas that absorb the radiation and convert it into alternating eddy currents. The frequencies of these radio waves fall in the low frequency microwave range (800- $2200 \mathrm{MHz}$ ), therefore, this radiation is of non- ion-}


izing type as the energy emitted is too low to break chemical bonds in biological system. On the other hand, the energy carried in extremely high frequencies $(1,000,000 \mathrm{MHz})$ electromagnetic waves such as X-rays is so intense that the electromagnetic particles have sufficient power to break chemical bonds and cause serious damage to human tissue; this type of radiation is known as ionizing radiation. Our article will discuss the male fertility hazards associated with the low frequency electromagnetic waves produced by cell phone technology $(1,2)$.

When speaking into a cell phone, the sound wave from the speaker goes through a transmitter that converts the sound into a sine wave. The transmitter then sends the signal to the antenna, which then sends it out into space in all directions. The transmitter in cell phone operates on about 0.75 to 1 watt of power, with $2 \mathrm{~W}$ at peak usage. This electric sine wave current running through the transmitter circuit also creates an electromagnetic field around it. As the electric current moves back and forth, the fields continue to build and collapse, forming electromagnetic radiation. Thus, cell phone radiation is generated in the transmitter, and is emitted through the antenna in the form of a radio wave (2).

Modern advances in cell phone telecommunication systems are associated with an increase in signal frequency, which correlates with higher energy radiofrequency waves. The first advent of the preliminary cell phone system was the Analogue NMT (Nordic Mobile Telephone) system which operated at $902.5 \mathrm{MHz}$ in the $1980 \mathrm{~s}$. A decade later, the GSM (global system of mobile communications) succeeded it, operating at a radiofrequency of 902.4 $\mathrm{MHz}$, pulsing at $217 \mathrm{~Hz}$. The most recent DCS (digital cellular system) operates at a radiofrequency of $1800 \mathrm{MHz}$ and has two additional low frequency magnetic fields associated with it (3).

Furthermore, specific countries differ in the frequency band at which the radio waves are transmitted. Most European and Asian countries networks operate at $850 / 900 \mathrm{MHz}$, while the United States network operates at 1800/1900 MHz. The higher the frequency the more energy the waves carry. With increasing globalization and demand for international travel, there are now phones which can operate in multiple countries, and are therefore considered "quad-band", receiving all signal frequencies 850/900/1800/1900 MHz.

The impact of these radio frequency electromagnetic waves on the human body is measured via a standardized unit called the SAR value. The SAR (Specific Absorption Rate) is a measure of the rate of radiofrequency energy absorption in the body and is calculated as watt $/ \mathrm{kg}$. Device specific SAR tests are conduced with the wireless device transmitting at its highest power level in all tested frequency bands. Since 1996, the FCC (Federal Communication Commission), has required that the maximum legal SAR of any handheld mobile device should not exceed 1.6 watts per kilogram (4). From the year 2000 onwards, all cell phone manufacturers must place labels on their phones disclosing their radiation level.

Although SAR is determined at a cell phones maximum power level, the actual SAR value of an operating wireless device may be less than the reported maximum. This value depends on multiple factors such as proximity to a cell site, the proximity of the wireless device to the body while in use, the mode of usage of the device (talk versus standby mode), and the use of hands-free (Bluetooth) devices (4).

Lastly, every country has specific government agencies, which are responsible for the regulation of electromagnetic radiation devices. In the United States there are the American National Standards Institute (ANSI), which is part of the Institute of Electrical and Electronics Engineers (IEEE), along with the FCC and the US Environmental Protection Agency; in the United Kingdom there is the National Radiological Protection Board (NRPB), and in Brazil there is ANVISA (Agencia Nacional de Vigilancia Sanitaria). Each agency is responsible for issuing evaluation bulletins, which highlight current regulations and also provide the government's stand on health concerns (4).

\section{Effects of Radio-Frequency Radiation on Gross Health}

The exact underlying pathophysiologic mechanism of cell phone related health impacts is not entirely known. However, there are two proposed cell 
phone related biological effects on the human body. The first is termed a "thermal effect" which occurs at particularly high frequencies where the radio-frequency radiation has heating properties which may lead to an increase in tissue or body temperature. Thermal effects may cause disruption of cell function and development (5). The inflicted tissue damage in humans could occur due to the body's inability to dissipate the excessive heat. The eye and the testes are particularly vulnerable due to relative lack of blood flow to dissipate the excessive heat load (6). The second is the "non-thermal effect" which is manifested by disruption of cell membrane integrity due to passage of electrically shaking eddy current formed from body absorption of EMW, endothelial dysfunction and alterations in the blood-brain barrier, cellular signal transduction effects, immune system effects and nervous system excitability defects (7-11). More realistically, the mode of action of RF-EMW is probably a combination of the thermal and nonthermal effects.

Many studies have analyzed the effects of cell phones on general human health (Figure-1). Alternation in electroencephalograph (EEG) pattern, sleep pattern and neuroendrocrine functions have been observed with increased cell phone usage $(12,13)$. Furthermore, usage of cell phones has been associated with difficulty in concentration, fatigue, and headache (14). Cell phone exposure has also been shown to increase resting blood pressure (15). Also, EMW radiation may alter hormone secretion, such as follicle-stimulating hormone, due to deformation of Leydig and Sertoli cells, which may lead to altered cell proliferation (16). Although it is not completely clear how the EMWs cause these changes, there is substantial evidence pointing towards a decrease in normal body function.

\section{Cell Phone Usage \& Male infertility}

Proper analysis of the impact of cell phone EMW on male reproductive function comprises careful examination of the available data retrieved from different animal and human studies on cell phone related semen alteration and deranged histological testicular changes.

\section{Altered semen quality in animal and human studies}

Infertility represents one of the most common diseases and affects between 17 and $25 \%$ of couples. Of these, male factor infertility is responsible for approximately $50 \%$ of the infertility cases (17). There are a number of studies, albeit limited in design, which point to cell phones as one of the causative agents in this increasing male contribution to infertility. Many studies suggest a link between cell phone usage and alterations in sperm count, motility, normal morphology, and viability (Table-1).

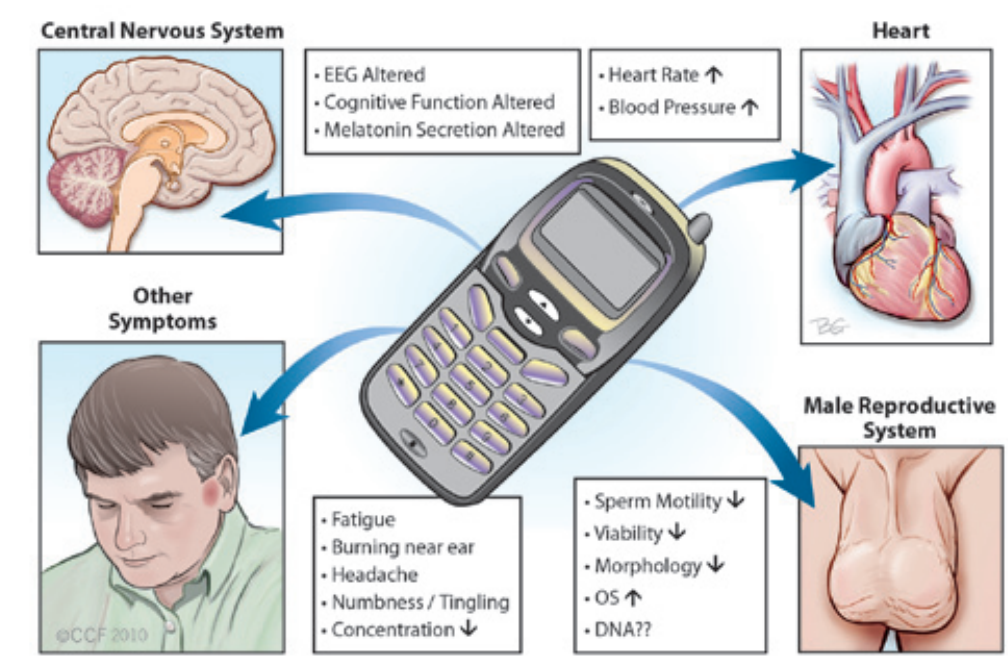

Figure 1 - Effects of Cellular Phone Usage on the Human Body. Usage of cellular phones is associated with alterations in various body systems including the central nervous system, cardiovascular system, and male reproductive system. Adapted from Makker 2009 (115). 


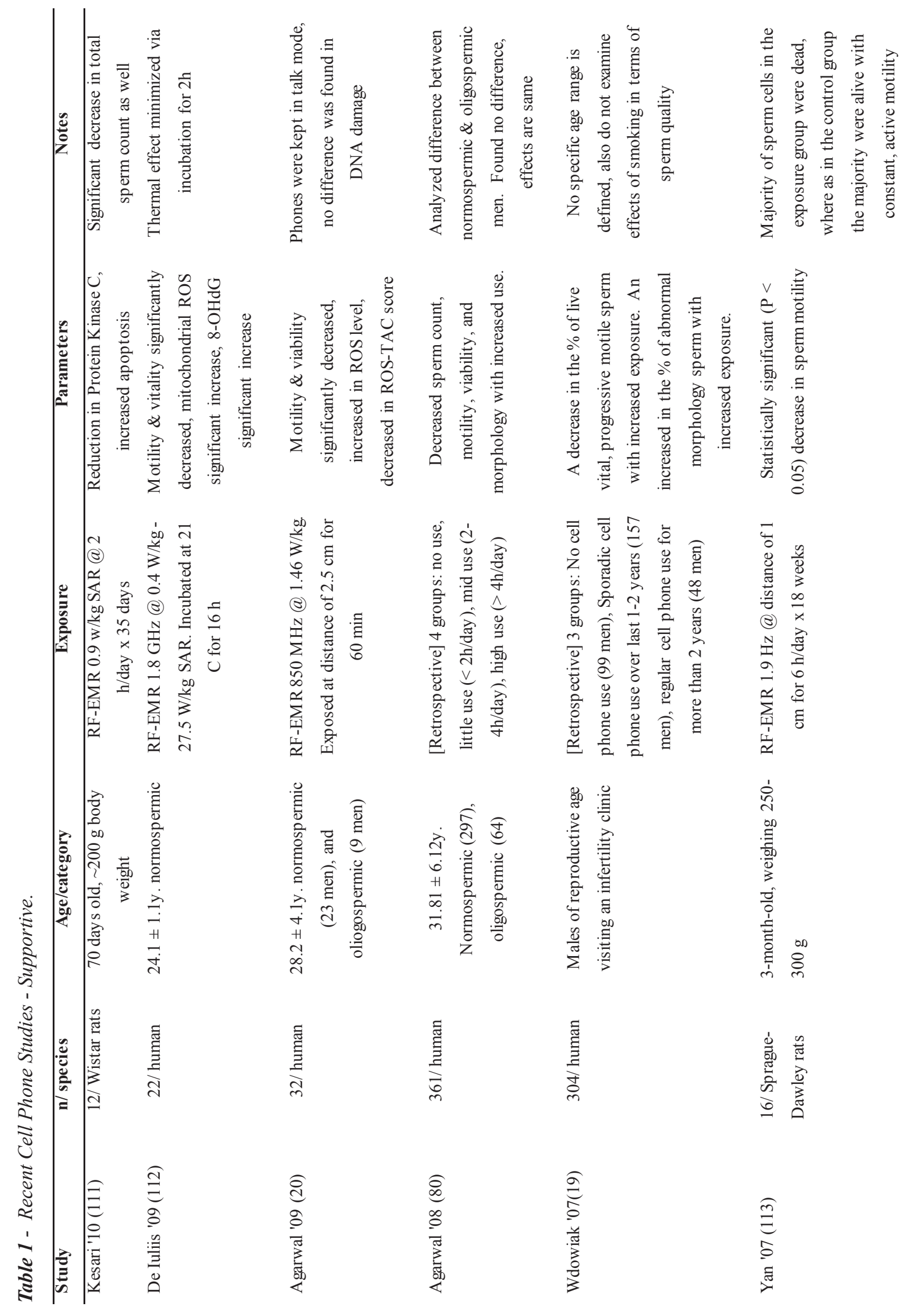



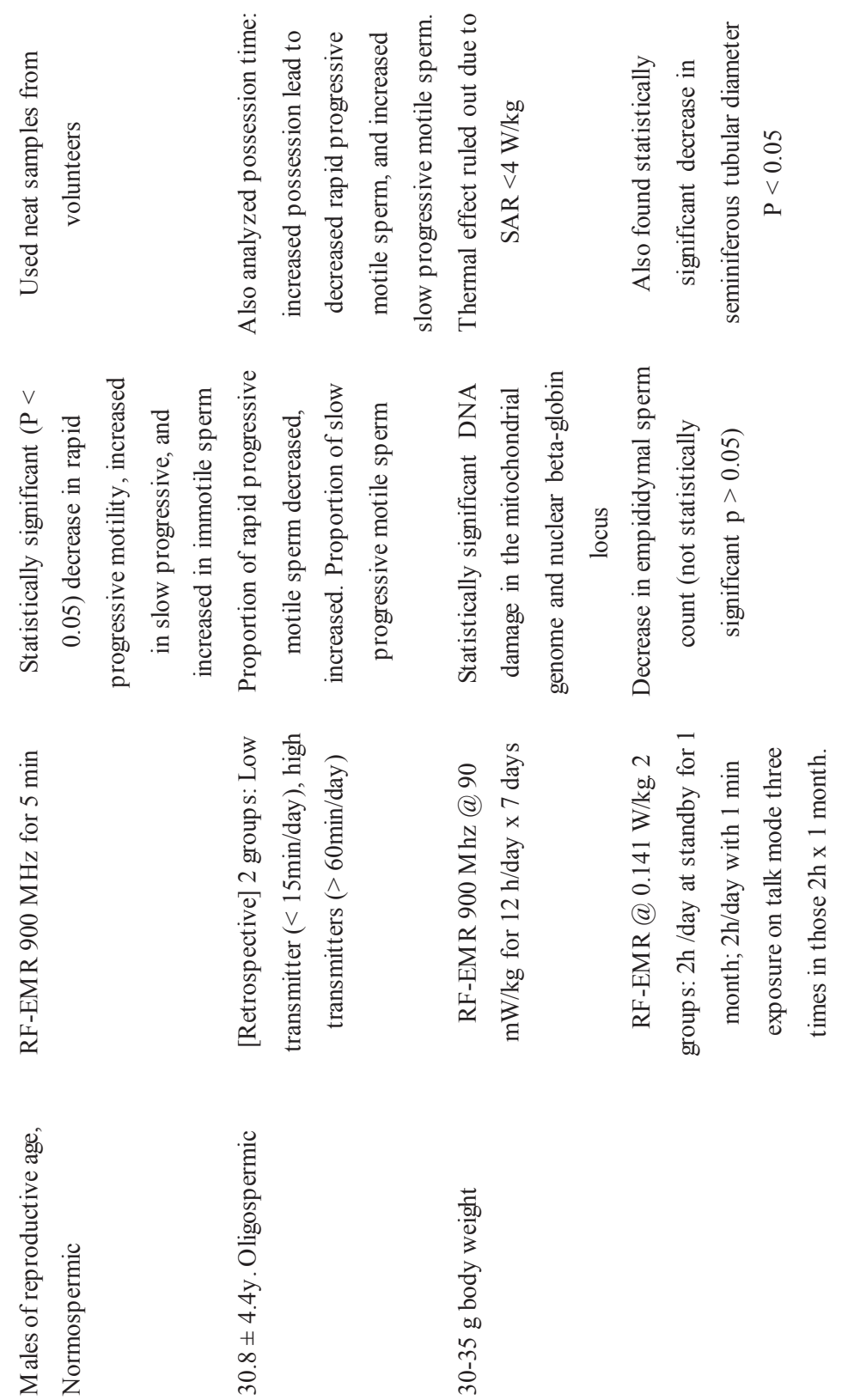

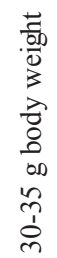

壳

킄

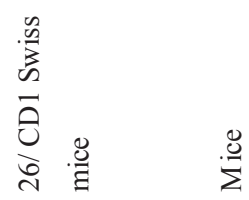

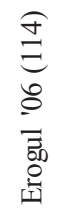

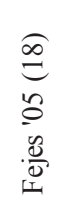

$\sqrt{2}$
6
0
0
0
0

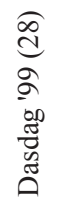


In a retrospective study involving 371 men of reproductive age, the duration of possession of cell phones and the daily transmission time had a significant negative correlation with the proportion of rapid progressive motile sperm $(r=-0.12$ and $r$ $=-0.19$, respectively), and a significant positive correlation with the proportion of slow progressive motile sperm ( $\mathrm{r}=0.12$ and $\mathrm{r}=0.28$, respectively) (Figure-2). Therefore, the prolonged use of cell phones may have negative effects on the sperm motility characteristics (18).

Wdowiak et al. performed another retrospective study involving 304 men of reproductive age and noted that there was a significant decrease in the percentage of sperm cells with normal forward progressive motility in correlation with the frequency of cell phone usage. In this study, $65.7 \%$ of patients without cell phones had over $50 \%$ of sperm with forward progressive motility whereas only $17 \%$ of patients who frequently (regular phone use for more than 2 years) used cell phones had over $50 \%$ of sperm with forward progressive motility (19).

Furthermore, Agarwal et al. conducted a prospective in vitro pilot study, exposing 32 neat semen samples to EMW radiation $(1.46 \mathrm{~W} / \mathrm{kg}$ SAR $\mathrm{x}$

A)

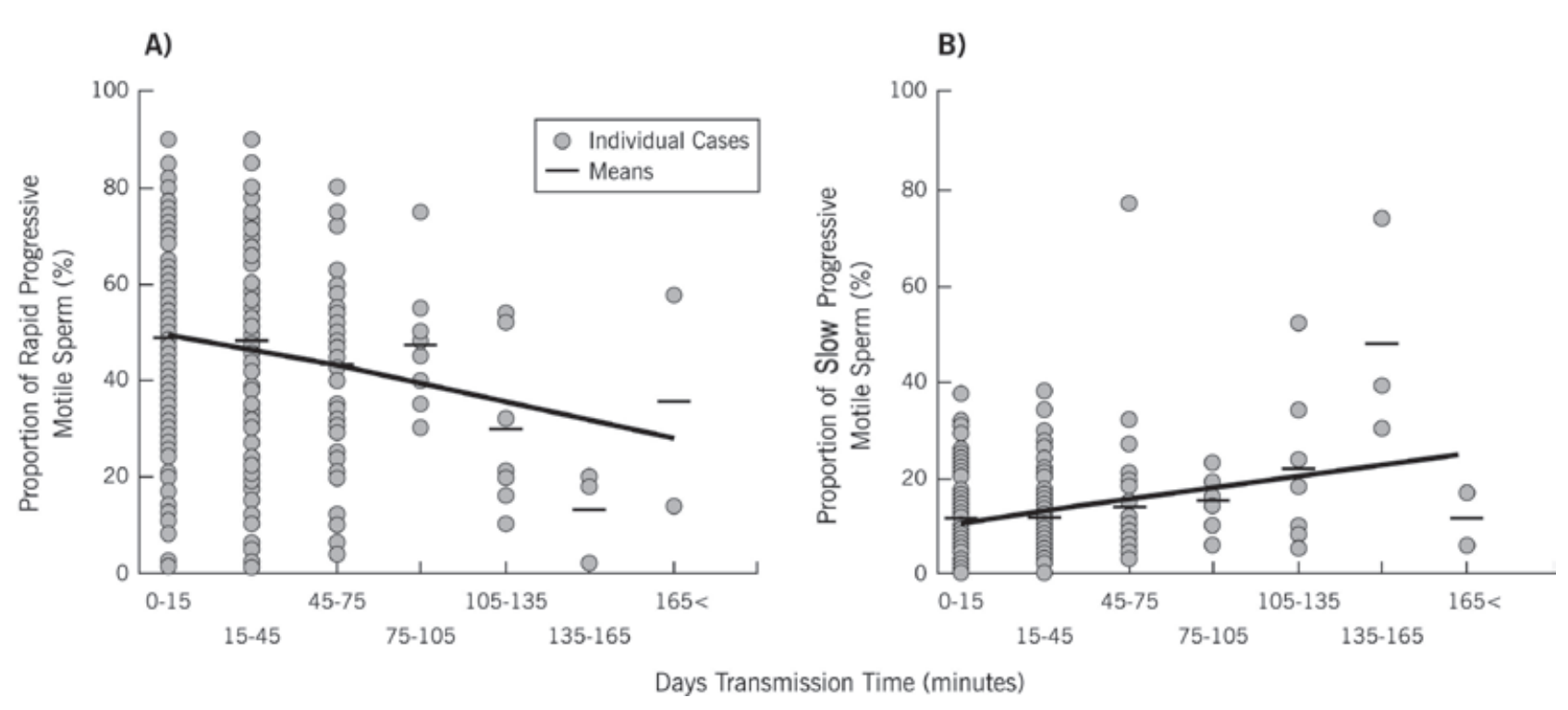

60 min.). The authors showed a significant decrease in sperm motility and viability, as well as an increase in ROS levels coupled with a decrease in ROS-TAC score, compared to the unexposed group. It was concluded that RF-EMW emitted from cell phones can lead to an increase in oxidative stress in human spermatozoa yielding decreased motility and viability characteristics (20). Lastly, a pilot study by De Iuliis explored that human spermatozoa shows dramatic decline in both sperm vitality and motility in response to RF-EMR (at $1.8 \mathrm{GHz}$ with a SAR of $27.5 \mathrm{~W} / \mathrm{kg}$ ) (21).

In addition to alterations in sperm motility, there are observed decreases in normal sperm morphology and count correlated with duration of cell phone usage. Wdowiak et al. noted a significant increase in the percentage of sperm cells with abnormal morphology associated with the duration of exposure to the EMW emitted by GSM cell phones. $55.6 \%$ of patients without cell phones had over 30\% normal sperm morphology, whereas only $16.7 \%$ of patients who frequently (regular phone use for more than 2 years) used cell phones had over 30\% normal sperm morphology (19).

Agarwal et al. carried out an observational study of 361 men to determine whether there is a cor-

Figure 2 - Cell Phone Usage and Sperm Motility.

A. Increasing cell phone usage (in minutes) is inversely correlated with the percentage of rapid progressive motile sperm.

B. Increasing cell phone usage (in minutes) is correlated with an increase in slow progressive motile sperm. Adapted from Fejes 2005 (18). 
relation between cell phone usage and sperm morphology. Men were divided into four usage groups: no use, $<2 \mathrm{~h} /$ day, $2-4 \mathrm{~h} /$ day, and $>4 \mathrm{~h} /$ day. The authors reported a statistically significant difference in mean WHO normal morphology between the low usage groups and the high usage groups $(40.32 \pm 13.06$ vs. $18.40 \pm 10.38)$. In addition, the same study found statistically significant differences in sperm motility and viability the usage groups (Figure-3) (22).

A Hungarian observational study on men attending infertility clinic showed significant reduction in sperm count related to cell phone handling. This study followed 231 men over a 13-month period, and showed that for heavy users of cell phones, sperm counts were, on average, $30 \%$ lower than men who did not have or use a cell phone (18).

Moreover, in an animal study when rats were exposed to electromagnetic radiation via cell phones ( $2 \mathrm{~h} /$ day $x 35$ days at $0.9 \mathrm{SAR})$, the exposed group had a decreased mean value of total sperm count (31.14 \pm 13.6 vs. $61.33 \pm 3.68)$, and an increased mean percentage of apoptotic cells $(13.15 \pm 1.26$ vs. $5.93 \pm$ $1.64 \%$ ) (23). Salama et al. conducted a study on rab- bits and showed that mobile phone (GSM mode, 800 $\mathrm{MHz}$, standby status) exposure for 8 hours/day led to a significant decline in the sperm count after 8 weeks of exposure and decrease in motility after 10 weeks of exposure (24). In contrast, other studies did not show a correlation between cell phone EMW radiation and alteration in sperm count $(9,18,25,26)$.

Overall, a large number of studies suggest a strong negative correlation between cell phone usage and a significant decreases in the normal characteristics of spermatozoa such as motility and morphology. However, there are conflicting reports regarding correlation with sperm count suggesting the need for more research in this area.

\section{Histological changes in male reproductive or- gans in human and animal studies}

Many animal studies examined the histopathological testicular changes due to cell phone EMW radiation. These changes are governed by the duration of cell phone exposure, SAR, and energy of the EMW. Reduction of testicular size has been noticed in varying reports (27). Other reports showed a de-

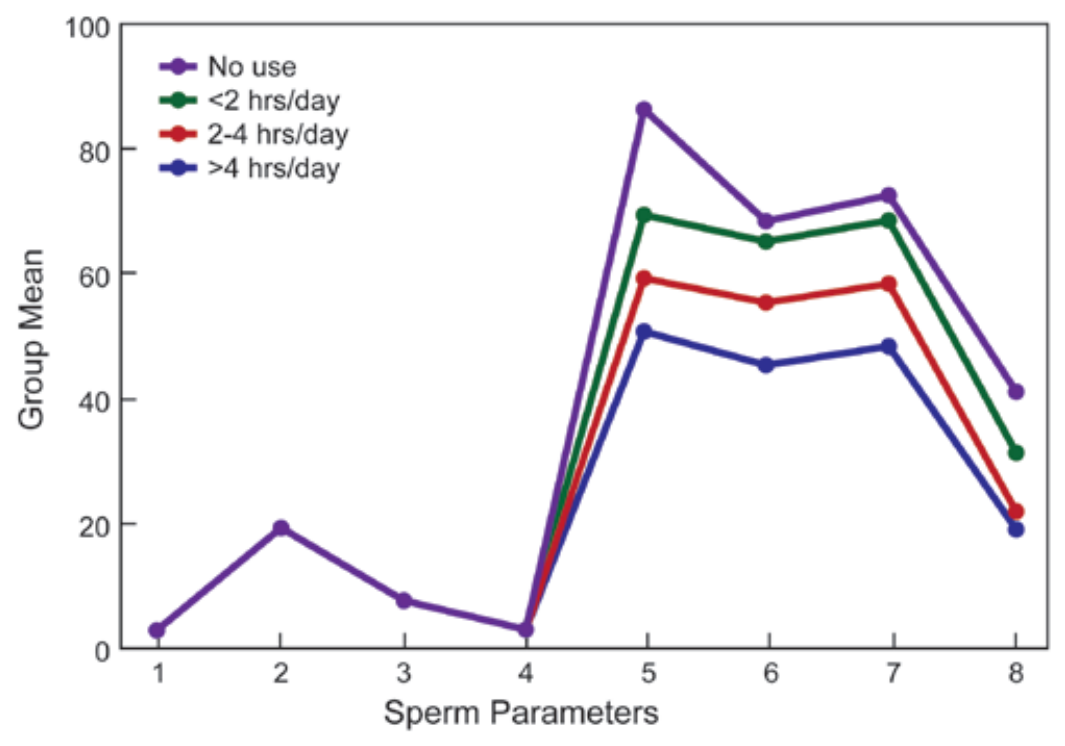

Figure 3 - Differences in semen parameters between cell phone users. The $x$-axis lists the eight sperm parameters which were studied between the four groups: $1=$ volume; 2 =liquefaction time; $3=p H ; 4=$ viscosity; $5=$ sperm count; $6=$ motility; 7 = viability; 8 = percent abnormal morphology. Parameters 1-3 showed not differences, whereas parameters 4-8 showed statistically significant differences between the low usage groups and the high usage groups. Adapted from Agarwal 2008 (80). 
crease in the diameter of seminiferous tubes and epithelial thickness $(24,26,28,29)$. Saunders and Kowalczuk showed significant degeneration of the mice seminiferous epithelium due to exposure to microwave radiation of $50 \mathrm{~mW} / \mathrm{cm} 2$ at a frequency of $2.45 \mathrm{GHz}$ for 30-40 minutes (30). Killari et al. were able to show EMW radiation related ultrastructural changes in seminiferous tubules, Leydig cells and spermatids in rats' testis (31). However many other studies found no histological changes in the animal testicular tissues exposed to the frequency of cell phone EMW (26,32-34). Moreover, there is a lot of controversy surrounding the usage of animals such as mice or rats to examine the possible deleterious effect of EMW on testicular tissues. This is due to the small size of the testis, their hidden position on the body, and their free mobility into the abdomen through the inguinal canal.

\section{Postulated mechanisms of cell phone related male fertility impairment}

There are several postulated mechanisms that can highlight the cell phone related impairment in male reproductive potential. All these mechanism rely on the common mobile phone effects on biological system, namely thermal and non-thermal effects.

\section{organs \\ 1. Thermal effects on male reproductive}

Testis depends mainly on surface conduction rather than blood flow for temperature control; this represents an important target for thermal effect of RF-EMW (28). Because the testis is a superficial organ, it may absorb more EMW energy than other organs. Human testes need physiological temperature $2^{\circ} \mathrm{C}$ lower than body temperature for optimal spermatogenesis and an elevation of testicular temperature may be reversible detrimental factor to sperm production $(35,36)$.

Some authors have demonstrated that acute EMW exposure can have direct effect on seminiferous tubular epithelium through increase in testicular temperature $(30,37,38)$. They exposed mice to 2.45 $\mathrm{GHz}(30 \mathrm{~W} / \mathrm{kg}), 1.7 \mathrm{GHz}(50 \mathrm{~mW} / \mathrm{cm} 2)$, and 2.45 $\mathrm{GHz}(44 \mathrm{~W} / \mathrm{kg})$ respectively and showed altered histology of seminiferous tubular epithelium and deranged semen parameters such as sperm count, sperm morphology. However, the EMW energy used in these studies is too high and greater than the EMW energy emitted by modern cell phones. Recent reports state that thermal effect of EMW emitted from commercial cell phones is negligible particularly at $\mathrm{SAR}<2 \mathrm{Watt} / \mathrm{kg}(8,9,39)$. It is estimated that only a SAR value greater than $4 \mathrm{~W} / \mathrm{kg}$ could result in a temperature increase of $1^{\circ} \mathrm{C}$.

Yan et al. conducted an animal study on rats in which rigorous measurements of surface and core body temperature were taken by sensitive electronic temperature probes placed adjacent to the rats' faces and rectums. The authors noticed that the mean face temperature of the experimental group exposed to the full 6 hours of EMW of cell phone at SAR of 1.80 $\mathrm{W} / \mathrm{kg}$ did not differ from that of the control group, and the rectal temperatures of both groups were virtually identical (9). Therefore, at this time there is no clear-cut evidence which supports the thermal effect of cell phone radiation on the human body.

\section{Non-thermal effects of cell phone ra- diation \\ This effect is still under scrutiny and com- prises a wide array of different metabolic pathways. The main mediator of these pathways is oxidative stress. However, direct damage of RF-EMW has been also implicated (Figure-4).}

\section{a - Oxidative stress}

Oxidative stress is established whenever there is excess production of ROS that overwhelms the neutralizing capacity of cellular antioxidants. Oxidative stress (OS) generated in the testicular organ due to mobile phone exposure leads to a build up of free radicals and ROS levels in sperm (40). OS has been implicated as one of the main culprit in male infertility (41-44).

Sperm are susceptible to damage from OS due to the high content of polyunsaturated fatty acids (PUFA) in their membranes and their limited stores of antioxidant enzymes (45). Oxidative stress has been known for some time to limit the fertilizing potential of human spermatozoa through 


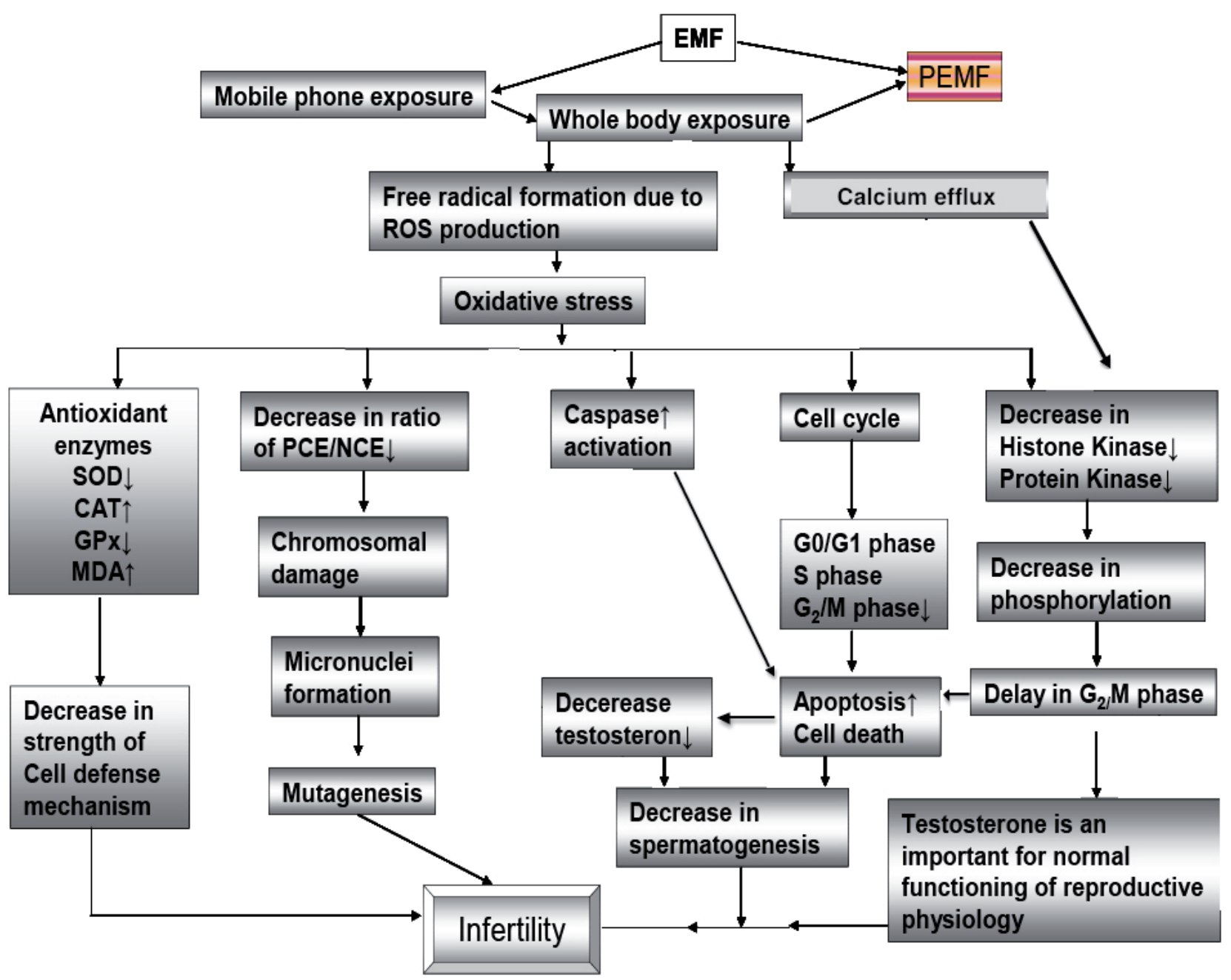

Figure 4 - A summaries of the biological effects of RF-EMR on male reproductive pattern. This figure indicates calcium efflux and enhanced ROS due to mobile phone radiation can cause several changes at enzymatic and hormonal level, which may result infertility. Adapted from Desai 2009 (27).

the induction of peroxidative damage to the sperm plasma membrane (46). ROS is also able to damage many biomolecules including DNA, enzyme, lipids, and protein.

Evidence of cell phone induced oxidative stress in semen comes from animal and human studies. Grundler et al. were the first to demonstrate that EMW induce free radical activity in cells $(47,48)$. Animal studies have shown various examples of cell phone induced OS in the eyes, brain, kidneys and endometrial lining of uterus $(48,49-52)$. Most recently, Kesari et al. have also shown a significant increase in ROS level in the semen of male rats exposed to mobile phone $(58.25 \pm 10.36 \mathrm{mg} / \mathrm{L})$ as compared with the semen of sham exposed animal $(41.78 \pm 12.93$ $\mathrm{mg} / \mathrm{L})(\mathrm{P}=0.035)(40)$.

Human studies also examined ROS and TAC in semen of men exposed to cell phone radiation in form of in vitro studies. Agarwal et al. divided neat semen samples from a group of fertile and infertile men into two aliquots. One aliquot (experimental) from each patient was exposed to cellular phone radiation (in talk mode) for $1 \mathrm{~h}$, and the second aliquot (unexposed) served as the control under iden- 
tical conditions (20). The authors discovered that samples exposed to RF-EMW showed a significant decrease in ROS level, and a decrease in ROS-TAC score, as well as a derangement of semen parameters such as motility and viability. Moreover, De Iuliis carried out a pilot study by exposing purified human sperm to a wide range of radio-frequency electromagnetic radiation (20). The authors reported that with increasing SAR, the cytoplasmic content of ROS as well as mitochondrial generation of ROS and DNA fragmentation were significantly increased accompanied by progressive decrease in sperm motility and vitality (21). The author showed that the power density and frequency range of mobile phones enhance mitochondrial ROS generation in human spermatozoa which stimulates DNA base adduct formation and ultimately causes oxidative DNA fragmentation (21). The source of the free radicals responsible for generating such stress appears to be the mitochondria. However, the factors responsible for inducing the mitochondria to leak electrons and propagate the production of ROS have not yet been elucidated (53).

On the other hand, Falzone et al. examined ROS production due to cell phone radiation on ejaculated, density purified, leukocyte free, highly motile human spermatozoa at two different SAR of 2.0 and $5.7 \mathrm{~W} / \mathrm{kg}$. There was no signficant difference in ROS production in comparison with the controls. These authors concluded that the excess ROS detected in other studies could be attributed to the presence of leukocytes, wherease these leukocytes were removed from their samples (54).

Besides the generation of ROS, the electromagnetic field emitted from various devices (mobile phones and microwave ovens) may also alter antioxidant enzyme activity $(27,40,55,56)$. Moustafa et al. demonstrated a decrease in the activity of antioxidant enzymes such as superoxide dismutase and glutathione peroxidase in erythrocytes in humans exposed to RF-EMW (57). Chronic exposure to RF-EMW decreases the activity of catalase, superoxide dismutase (SOD) and glutathione peroxidase (GSH-Px), and thus decreases the total antioxidant capacity in different organs of the body $(26,28,32,51,58)$. A decrease in the level of
SOD activity suggests an increase in the generation of reactive superoxide ions (59).

Regarding seminal level of antioxidant enzymes, Kesari et al. conducted animal studies to examine the changes in antioxidant enzymes in response to cell phone exposure. They confirmed a decrease in glutathione peroxidase and superoxide dismutase and an increase in catalase levels at SAR $0.9 \mathrm{~W} / \mathrm{kg}(40)$.

Studies have also demonstrated that antioxidants such as melatonin, caffeic acid, phenyl ester, vitamin $\mathrm{C}$, and vitamin $\mathrm{E}$ prevent oxidative stress or apoptosis caused by RF-EMW in different animal tissues $(49,50,58)$. There has also been a demonstrated reduction in 6-hydroxymelatonin sulfate (6-OHMS) level in the urine among individuals using a cell phone for over 25 minutes/day (60). 6-OMHS is the urinary metabolite reflecting the serum level of the pineal hormone melatonin. Melatonin is a known antioxidant which protects against lipid peroxidation in the retina, brain, liver cells, and human sperm (61). Therefore, exposure to cell phones may be correlated with significant decrease of melatonin in the body, making spermatozoa more susceptible to reactive oxygen species attack.

It can be concluded that the increased risk of oxidative stress in semen due to cell phone radiation is real. However, this risk burden is determined by duration of handling of phones, frequency of EMW, SAR and proximity to the male reproductive organs.

\section{b-Alteration of sperm cell mem- brane potential and signal transduction}

EMW can generate alternating current across negatively charged cell membrane when our bodies act as antennas that absorb the EMW radiation and convert it into alternating eddy currents. Cations such as calcium and magnesium bind naturally to negative charged cell membrane which contains islands of proteins embedded in a sheet of negatively charged phospholipids. Positive ions fit between the negatively charged phospholipid molecules and reduce their tendency to repel one another contributing to cell membrane stability (62-64). Pulsed radio waves from mobile 
Figure 5 - Effects of RF-EMW on cellular macromolecules.

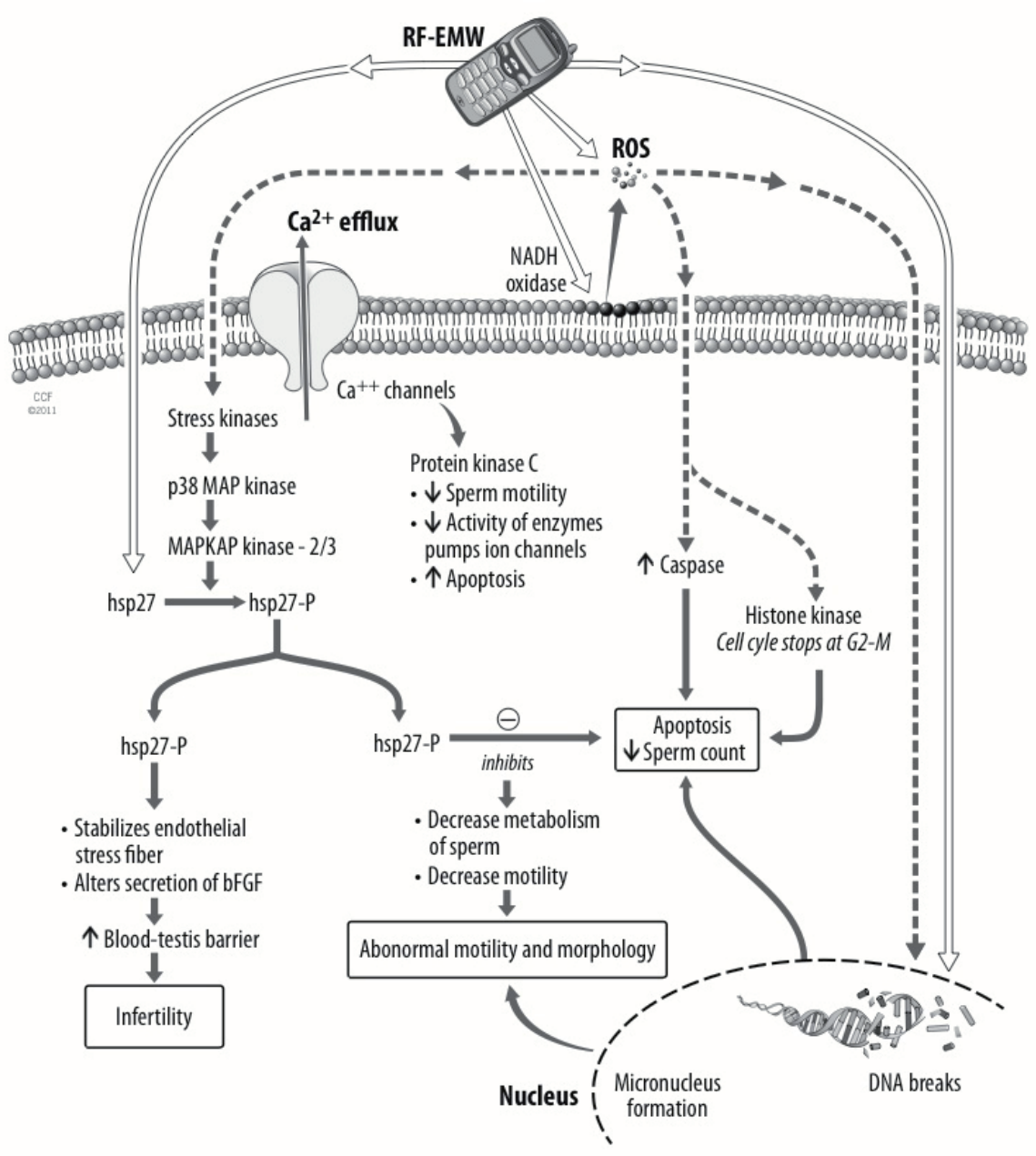

The figure shows various cellular targets of radiofrequency electromagnetic waves (RF-EMW). Exposure to RF-EMW can induce alteration in plasma membrane potential and calcium efflux with resultant calcium depletion which leads to decrease the activity of protein kinase $C(P K C)$. This decrease leads to alteration in many enzymes, ion pumps, channels and proteins as well as inducing apoptosis. RF-EMW induces ROS production through effect on mitochondrial membrane bound NADH oxidase. ROS has impact on PKC, histone kinase, heat shock protein, DNA and apoptosis. Heat shock protein (hsp) increase in response to electromagnetic radiation and ROS. Hsp slows the metabolism of the sperm and impairs the blood testis barrier. Hsp interferes with apoptosis of damaged and transformed sperm. Genotoxic effect of RF-EMW on sperm is either through ROS production or through direct clastogenic chromatin breaking effect.

phones generate shaking currents that drive calcium ions on and off the membranes (65-68). The depleted calcium is replaced by potassium, which renders the cell membranes weak and leaky, because potassium has limited ability to stabilize the membrane. The evidence of this EMW effect on cell membrane is revealed by electrophysiological studies on nerve cells.
Sperm are electrically active motile cells and their flagellar motility is determined by cAMP and calcium content. Calcium efflux from the cell in response to the eddy currents across the plasma membrane leads to impaired sperm motility which can be seen in various studies (69-72). Furthermore, The altered calcium homeostasis has dramatic consequences on other metabolic pathways in the cell 
because calcium is one of the intracellular secondary messenger molecules (Figure-5). Protein kinase $\mathrm{C}$ (PKC) is one of these pathways. PKC is a family of enzymes that are involved in controlling the function of other protein pumps and channels through the phosphorylation of hydroxyl groups of serine and threonine amino acid residues in these proteins (7377). PKC enzymes in turn are activated by signals such as increases in the concentration of diacylglycerol or $\mathrm{Ca} 2+$. Hence PKC enzymes play important roles in several signal transduction cascades such as mediating cellular responses to extracellular stimuli involved in proliferation, differentiation, apoptosis, and exocytotic release in a number of non-neuronal and sperm cells (74-77). Moreover, PKC is localized in the equatorial segment of the sperm and in the principal piece of the flagellum and hence plays a role in sperm motility $(78,79)$. Therefore, a decrease in PKC activity, induced by cell phone usage, may lead to a decline in flagellar activity, thereby negatively affecting sperm motility.

Kesari et al. found a decrease in the levels of PKC activity in adult male Wistar rats (12 rats, 70 days old, approximately 200 g body weight) when exposed to EMW radiation $(0.9 \mathrm{w} / \mathrm{kg}$ SAR x 2 h/day x 35 days) (23). Cell phone radiation-related increase in ROS and/or calcium efflux leads to decrease activity of PKC. Also, radiation from cell phones may cause alterations in the mitochondrial membranes of human spermatozoa, leading to changes in ATP production, which decreases overall power availability to the sperm, and thus decreasing motility (80).

Short-term exposure to RF-EMW may also lead to an increase in the activity of plasma membrane NADH oxidase enzyme, which in turn increases ROS formation (10). Chronic exposure to EMW radiation, in association with excess ROS exposure, leads to activation of heat shock proteins (hsp) as a protective response (81). The job of these hsp is to combine with vital enzymes, forming a protective layer around these enzymes. This in turn shields them from damage. However, this activation stops the hsp from working properly and interferes with metabolism of the sperm (Figure-5). In addition, heat shock proteins have been discovered to stabilize endothelial stress fiber and alter secretion of basic fibroblast growth factor (bFGF). This in turn can lead to an increase in the permeability of bloodtestis barrier and cause infertility (27).

\section{c- Alteration in sperm prolifera- tive activity and apoptosis}

Spermatogenesis is an active proliferative process consisting of two phases: the mitotic phase and the meiotic phase. The cell cycle is regulated by a control system formed by molecules that trigger and coordinate key events. These molecules act primarily on two important check points in the cell cycle, G0 to G1, and G2 to M. Protein kinases are the best examples of such molecules because they can activate or deactivate other proteins via phosphorylation. However, these kinases themselves require a second protein, a cyclin, to become activated. Histone kinase is one such protein, containing a $\mathrm{Cdc} 2$ catalytic subunit which must bind with cyclin B to form a maturation promoting factor. This activated Histone kinase thereby regulates the transition from $\mathrm{G} 2$ to $\mathrm{M}$ $(82,83)$.

Phosphorylation and dephosphorylation of histones is the prime mechanism observed in metaphase and anaphase respectively in both meiosis and mitosis. Decreased activity of histone kinase in sperm has been associated with defective progression in the cell cycle and defective spermatogenesis. Kesari et al. have shown a statistically significant decrease in mean activity of histone kinase 1 in semen of rats post EMW radiation (SAR $0.9 \mathrm{~W} / \mathrm{kg}$ ) as compared to the controls. This decline in the level of histone kinase, indicates a decrease in $\mathrm{G} 2 / \mathrm{M}$ phase activity (Figure-5) (40).

As aforementioned, PKC is the key regulator of many cellular processes including the cell cycle. Decrease in the PKC activity is associated with a decline in $\mathrm{G} 2 / \mathrm{M}$ transition and increase in the apoptotic phase (23). Kim et al. reported that longterm exposure to EMF has adverse effects on the proliferation and differentiation of spermatogonia, which may be important in understanding the pathogenesis of EMF induced male infertility (84).

There are reports on the effect of cell phone radiation in provoking apoptosis in sperm. 
Apoptosis is a programmed cellular death, a natural process required to remove old and senescent sperm. During spermiogenesis, apoptosis plays a key role in adjusting the appropriate number of proliferating germ cells associated with the surrounding Sertoli cells. However, there are certain external factors which may lead to an increase in the rate of apoptosis, such as exposure to radiation and presence of $\mathrm{H}_{2} \mathrm{O} 2$. Kesari and Behari have reported increased apoptosis in Leydig cells of testis due to microwave exposure at $2.45 \mathrm{GHz}(0.11 \mathrm{~W} / \mathrm{kg}$ of SAR x 35 days of exposure) (85). The same study showed an increased DNA fragmentation index (DFI) in sperm resulting from exposure to mobile phone and microwave oven frequencies. The DFI was measured by TUNEL (apoptosis detection assay) and confirmed with flowcytometer $(85,86)$.

The regulation of apoptosis is based on the intracellular dominance of various proteins that induce or inhibit the apoptotic process, such as BAX, Bcl and caspase-3. (87). Caspases are present as inactive precursors and activated by initiator caspase through autoactive proteolysis (88). The initiator caspases 8 and 9 with effector caspase 3 are considered the main executors of apoptosis (89). The effector caspase 3 shares both pathways - mitochondrial pathway through caspase 9 and deathreceptor pathway through initiator caspase 8 (90). The mitochondrial pathway is triggered by various intracellular stimuli (for example DNA damage, cytoskeletal damage, endoplasmic reticulum stress, and macromolecular synthesis inhibition) that induce mitochondrial outer membrane permeabilisation (MOMP), which is followed by the release of cytochrome $\mathrm{c}$ and the formation of the apoptosome (91). Usually caspase-9 and caspase-3 are activated to execute apoptosis. Caspase-3 activities were increased in in-vivo studies in mice and rat L929 cells after exposures to RF radiation, indicating effects on apoptosis (92). Kesari et al. reported an increase in rate of apoptotic sperm $(\mathrm{P}<0.005)$ with a significant decrease $(\mathrm{P}=0.022)$ in $\mathrm{G} 2 / \mathrm{M}$ phase after 2 hours of mobile phone exposure for 35 days (40).

However, an induction of increased hsp27 activation by the RF-EMW exposure may also lead to inhibition of the apoptotic pathway (involving apoptosome and caspase 3) (27). This event, when occurring in RF-EMF exposed cells, that previously underwent either spontaneous or external factor-induced transformation/damage, could support survival of these transformed or damaged cells (93). Caspases activated by apoptotic signals cleave various cellular substrates such as actin, poly (ADP-ribose) polymerase, fodrin and lamin, which may be responsible for the morphological changes that occur in the cells. Therefore, activation of apoptosis and concurrent activation of anti-apoptotic pathways may be responsible for increased morphological abnormalities in sperm which have been shown in various studies (Table-1).

\section{d- Mobile phone induced DNA damage and micronuclei formation}

The effects of RF-EMW on DNA damage have been demonstrated in different tissues and in various studies in the last decade (9498). De Iuliis et al. have shown high level of sperm DNA damage due to RF-EMW and reported that this damage is mainly oxidative in nature (21). Aitken et al. reported significant damage to the mitochondrial and nuclear genome in epididymal spermatozoa of mice exposed to RF-EMW (900 $\mathrm{MHz}$ for 12 hrs/day x 7 days) (25). By compiling the data from various studies in different tissue, the risk of EMW related DNA damage is seemingly real, particularly when there is clear evidence of increased oxidative stress.

The other evidence for EMW induced chromatin damage comes from identification of micronuclei. Micronuclei (MN) are small bodies in the cytoplasm in the vicinity of the nucleus of the interphase cells. These micronuclei may originate from acentric fragments (chromosome fragments lacking a centromere) due to clastogenic mutagen or from whole chromosomes which are unable to migrate with the rest of the chromosomes during anaphase of cell division (lagging chromosome) due to aneugenic mutagen. Micronucleus testing is one of the more sensitive tests used to identify the genotoxic effect of a broad range of the mutagenic and presumably carcinogenic pharmaceutical compounds and radiation exposure in somatic and germ cells (99). 
Cell phone EMW radiation may have a clastogenic impact on chromatin integrity. To investigate this damage, micronucleus testing is implemented. The micronucleus assay usually uses animal bone marrow and/or peripheral blood erythrocytes exposed to potential genotoxic sources, such as cell phone radiation, to test for chromatin damage. Counting of micronucleated Polychromatic Erythrocytes (PCE) and the ratio of PCE/NCE (normochromatic erythrocytes) in stained slides is performed. Flowcytometry is also used due to its sensitivity and specificity over manual counting. The normal PCN/NCE ratio is reported to be 1:1 in bone marrow. An increase in NCEs signals a cytotoxic effect; whereas an increase in PCEs reflects a stimulation of erythrocyte proliferative activity (100). Furthermore, an increase in micronucleated PCEs in the bone marrow gives clear evidence of chromatin insult (100). Kesari et al. recently showed a significant increase $(\mathrm{P}<0.002)$ in micronucleated PCEs of mobile phone exposed group $(0.67 \pm 0.15)$ as compared with control group $(1.36 \pm 0.07)$, where a decrease was recorded by comparing the ratio of PCE (polychromatic erythrocyte) and NCE (normochromatic erythrocyte) in blood cells. They also found a significant increase in MN levels in bone marrow cultures when irradiated at a mobile phone frequency for 35 days (SAR $0.9 \mathrm{~W} / \mathrm{kg}$ ) (40).

Specifically speaking, it is now clear that cell phone EMW even at a SAR of $0.9 \mathrm{~W} / \mathrm{Kg}$ can have harmful effects not only at the DNA level but also at the chromatin level (Figure-5). However, it is not clear whether EMW radiation has a direct breaking effect on chromatin or exerts the damage through other mediators such as ROS.

\section{to EMW radiation}

\section{e- Hormonal changes in response}

Testes perform two important functions: spermatogenesis and steroidogenesis. Leydig cells secrete testosterone which has the regulatory role in stimulating and maintaining sperm production. Also, the pituitary gland regulates male reproduction through production of luteinizing hormone (LH) and follicle stimulat- ing hormone (FSH). LH stimulates Leydig cells to produce testosterone and maintains their function. The impact of cell phone EMW radiation on testicular steroidogenesis is thereby examined in two circumstances: on Leydig cells and on the pituitary gland.

Nearly all the studies in this field were conducted on animals to control the exposure and to ensure that the measured variables are related to the exposed electromagnetic radio waves. Wang et al. suggested in their study on mice, that Leydig cells are among the most susceptible cells to EMW and that injury to these cells may affect spermatogenesis (101). Oxidative stress and EMW induced alteration in PKC enzyme complex which is present in seminiferous tubules and Leydig cells, can explain the deranged function of Leydig cells in response to cell phone (77).

Also, a decrease in serum testosterone in the exposed group in comparison to the controls was observed (101). EMW not only alters serum testosterone, but also affects the expression of mRNA for P450 cholesterol side chain lyase (the first enzyme in steroidogenesis) in Leydig cells (102). Serum testosterone was significantly reduced in EMW exposed group compared to the control group $(\mathrm{p}<0.05)$; although there were no demonstrable changes in $\mathrm{FSH}, \mathrm{LH}$, or interstitial histology. The authors concluded that the normal FSH and LH levels may be explained by minimal exposure of EMW on the anterior pituitary which leads to inhibition of excessive FSH and LH release in response to low testosterone (29). In addition, Forgacs et al. found an increase in testosterone level in the experimental group after a two week exposure (33). Moreover, Salama et al. measured androgen-dependent secretory activity of accessory sex glands in rabbits exposed to cell phone radiation, and discovered significant decline in seminal plasma fructose in the exposed group (post 10 weeks of exposure). However, the authors did not find any difference in serum testosterone levels between study groups. These findings were attributed to possible alteration in testosterone receptors or increased oxidative stress on male accessory glands (103). 
The pituitary gland and subsequent gonadotropins production have also been studied in humans and animal models exposed to EMW emitted from cell phones. De Seze et al. examined the gonadotropins concentrations of anterior pituitary hormones FSH and LH in 21 healthy males after applying $900 \mathrm{MHz}$ RF radiation emitted from a cell phone (2h/day x 5 days/week x 1 month) and found no effect (104). However, the duration of $\mathrm{RF}$ radiation exposure in their study might not be sufficient to produce any significant effect. Other studies also failed to prove pituitary gonadotropins alteration in humans or animals exposed to cell phone $(33,105,106)$.

However, a recent report by Fang et al. showed progressive histological derangement in rats' pituitary glands exposed to high level of EMW $(200 \mathrm{kv} / \mathrm{m})$ in form of swollen mitochondria as well as dilatation of Golgi complex and diffusive lysosomes. With increasing duration of exposure and EMW energy, mitochondrial vacuolization, formation of myelin figures, distinct dilatation of endoplasmic reticulum, occurrence of numerous secondary lysosomes, and clustering of heterochromatin under the nuclear membranes could be observed (107). Despite the fact that the level of electrical field strength used in this experiment is higher than the current level found in modern cell phones, it should be noted that this level of radiation can cause substantial damage. Therefore, every effort should be undertaken to prevent any further increase in the radiation and electrical strength levels found in today's cell phones.

\section{Controversy regarding cell phone studies}

In the past dozen years there have been many studies which suggest a possible detrimental effect of cell phone usage on spermatozoa and male fertility (Table-1). However, there have been just as many studies which suggest there is no correlation between among mobile phone electromagnetic wave radiation and semen parameters (Table-2). Why it is that such controversy and debate exists? The answer to this heated question lies in the difficulties that arise when designing a cell phone study.
Repeatable study design is hard to achieve due to a variety of factors including an appropriate control group, cell types used, and testing protocol. For every scientifically conclusive study there must be an appropriate control group against which results of a stimulus can be compared. Unfortunately, for cell phone studies in humans it is often difficult to attain a standardized group of individuals of reproductive age who have never had exposure to any form of mobile telecommunications device. When individuals lacking exposure to cellular devices are found, they are often older, introducing plethora external variables into the experiment including age-related fertility decline, and increased lifelong exposure to toxins. Therefore individuals with "minimal" exposure to cell phone electromagnetic radiation are often used as a baseline during in vivo testing.

Experiment design is yet another large deterrent to conclusive results concerning cell phones and human health. There is no standardized assay for analyzing the effects of cell phone exposure. No generally accepted SAR testing value has been agreed upon, cell types in the context of spermatozoa maturity and origin (testis vs. epididymis) vary from experiment to experiment, and even the models for exposure differ. Variations in the distance between the mobile device and the exposed sample or testis, length of exposure in various transmission modes (standby vs. talk), and even the type of mobile device used are all variables which contribute to the ambiguity of results regarding cell phones.

Moreover, the SAR in a biological body depends on several exposure parameters such as frequency, intensity, polarization, radiation sourcebody configuration (the far-field and the near-field) and the presence of reflecting surfaces nearby. The SAR also depends on the size, shape and electrical properties of the body. The spatial distribution of the SAR inside the body is usually highly nonuniform and depends on all of the above parameters. Animals have different body sizes, anatomical characteristics of reproductive tract and geometry from human and these differences make the application of the results of animal studies on human is seemingly arguable. 


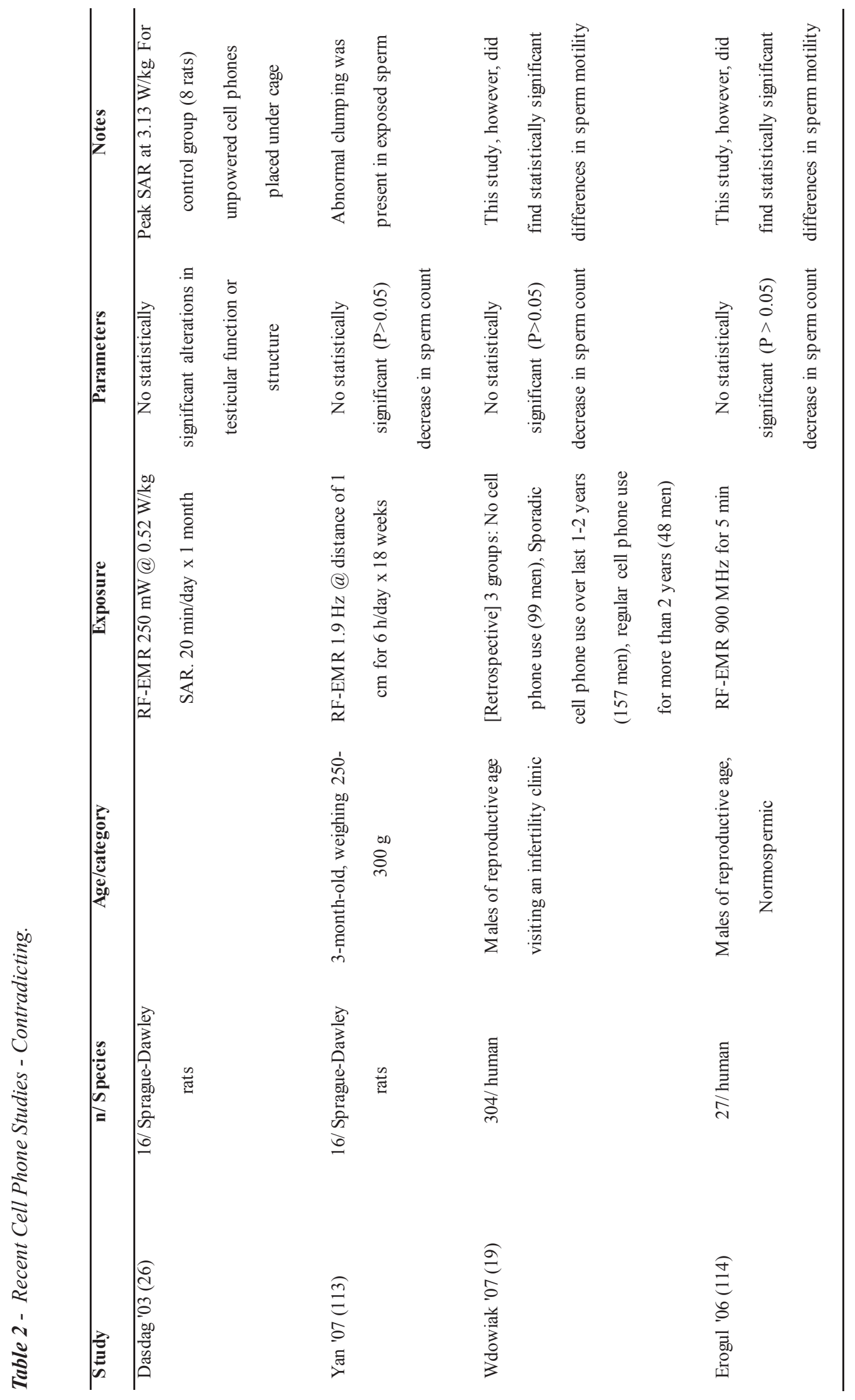


Furthermore, there are ethical considerations that must be taken into account which inhibit exposure testing in vivo. For this reason trials must be conducted either in animal models or in vitro ejaculated samples. One complication that arises when using ejaculated neat samples is determining the exact location of the exposure device which would mimic real life conditions. In order to establish a reliable standard for distance between the device and the sample, our group conducted a series of simulations using the Finite Difference Time Domain (FDTD) method. This method provided a computer-assisted simulation showing the equivalent effect of multiple tissue layers between an EMW emitting cell phone and the spermatozoa in the testis. Our results showed that in order to mimic in vivo exposure, the distance between a cell phone and an ejaculated semen sample should be $0.8 \mathrm{~cm}$ to $1.8 \mathrm{~cm}$ greater than the anticipated distance between the cell phone and the testis (108). Using these results we can now establish more accurate future studies.

Lastly, government agencies release ambiguous notices concerning cell phone exposure and human health. For example, the U.S. Food and Drug Administration (FDA) states "the scientific community at large believes that the weight of scientific evidence does not show an association between exposure to radiofrequency from cell phones and adverse health outcomes. However, the scientific community recommends conducting additional research to address gaps in knowledge" (109). Until there is a formalized assay for testing, which accounts for external variables and has an appropriate control group, no substantial conclusions can be drawn regarding cellular telephones, their associated electromagnetic wave radiation, and alterations to human health.

\section{What does the future have in store?}

As our race continues to develop and increase in technological complexity, our cell phones must also improve. Old "talk and text" phones have been replaced with the "Smartphone", and large, multifunction touch screens have outdated actual keys. However, one rarely stops to think what these advances may mean in terms of our health.

There has been a demonstrated increase in the SAR of popular mobile phones. In 2005 the hottest "must have" mobile device was the Motorola RazR, which carried an associated 0.89 SAR. Then in 2007, Apple introduced its iPhone, forever changing the mobile telecommunications industry. However, this new device came with a SAR of 0.98. Then again in 2008, Apple introduced a newer, more advanced iPhone $3 \mathrm{G}$, giving the user the capability to carry around the Internet in their pocket. However, they also delivered us a SAR of 1.388 (110). The industry replies to the user's demands and the advances in technology delivers not only increasing capability but also higher SAR.

Furthermore, globalization has allowed the consumer to bypass country boundaries and purchase consumer goods previously unavailable or restricted. The frequent international traveler can now purchase cellular phones which can function on all four signal frequencies: 850, 900, 1800 and $1900 \mathrm{MHz}$. These "quad-band" phones may be convenient for the globetrotters, yet the increased capabilities may mean additional health risks.

However, not all technological advances are increasingly detrimental to human health. Recently in the United States, AT\&T chose to switch from a $1800 \mathrm{MHz}$ signal frequency to $850 \mathrm{MHz}$ signal frequencies, in order to keep up with user demand. This switch provides customers with better quality calls due to decrease in traffic over the network; and it also allowed for AT\&T to provide a reliable nationwide Internet service for their mobile devices, the $3 \mathrm{G}$ network. This change utilizes a lower intensity signal and therefore may be less detrimental to the user.

\section{CONCLUSIONS AND FUTURISTIC VIEW}

Today's advances in technology may be associated with increasing risk to the human user. While no certain conclusions can be drawn from the evidence, a growing number of studies indicate a decrease in male fertility associated with cellular 
phone usage. These cellular devices emit radio frequency electromagnetic waves which may hinder spermatozoa quality as well as encumber normal bodily functions. Our review presents data which both supports and rejects these claims. The antagonistic data is due to the lack of a standardized assay for mobile device analysis. Until there is a formalized test, which includes an adequate control group, no conclusive results can be drawn.

The SAR in a biological body depends on several exposure parameters such as frequency, intensity, and polarization. The SAR also depends on the size, shape and electrical properties of the body. Exposure of the testis and secondary sex organs to RF-EMW's has shown a detrimental effect on spermatozoa. Changes on the macro-scale (morphology, motility, and count) as well as the microscale (PKC, HSP, histone kinases) can be observed. The exact mechanisms of how this RF-EMW may affect the spermatozoa have not yet been verified, although many feasible models have been proposed.

Cellular phones are a vital part of everyday life, and additional studies are needed to evaluate the consequences of increasing usage of new-age "Smartphones." Based on the results of future studies, government may decide on new regulations to reduce the risks associated with cell phone usage.

\section{CONFLICT OF INTEREST}

None declared.

\section{This work was supported by the Center for Reproductive Medicine, Cleveland Clinic}

\section{REFERENCES}

1. Digital Wireless Basics: Frequencies V Cellular, PCS, GSM, and Japanese Digital Cellular Frequencies. 2007; Available at: www.privateline. com/PCS/Frequencies.htm

2. How cell-phone radiation works. 2007; Available at:http://www.howstuffworks.com/cell-phone-radiation.htm
3. Roelandts R: Cellular phones and the skin. Dermatology. 2003; 207: 3-5.

4. Cleveland Jr JR, Sylvar DM, Ulcek JL: Evaluating Compliance with FCC Guidelines for Human Exposure to Radiofrequency Electromagnetic Fields. OET BULLETIN 65, Edition 97-01 [monograph on the Internet]. 1997 [cited 2011 Feb 10]. Available from: Federal Communications Commission Office of Engineering \& Technology, Office of Engineering \& Technology Web site: http://www.fcc.gov/Bureaus/Engineering_Technology/Documents/bulletins/ oet65/oet65.pdf

5. Deepinder F, Makker K, Agarwal A: Cell phones and male infertility: dissecting the relationship. Reprod Biomed Online. 2007; 15: 266-70.

6. National Radiological Protection Board (NRBP). Review of the scientific evidence for limiting exposure to electromagnetic fields $(0-300 \mathrm{GHz})$. Documents of NRPB [monograph on the Internet]. 2004 [cited 2011 Feb 15].; 15(3) Available at: National Radiological Protection Board (NRPB), Chilton, Didcot, Oxon: NRPB Web site: http://www.hpa.org.uk/web/ HPAwebFile/HPAweb_C/1194947383619

7. World Health Organization. 2006 WHO Research Agenda for Radio Frequency Fields, [homepage on the Internet]. 2006 [cited 2011 Feb 15]. Available at: World Health Organization, Web site: http://www.who. int/peh-emf/research/rf_research_agenda_2006.pdf

8. Straume A, Oftedal G, Johnsson A: Skin temperature increase caused by a mobile phone: a methodological infrared camera study. Bioelectromagnetics. 2005; 26: 510-9.

9. Yan JG, Agresti M, Bruce T, Yan YH, Granlund A, Matloub HS: Effects of cellular phone emissions on sperm motility in rats. Fertil Steril. 2007; 88: 957-64.

10. Friedman J, Kraus S, Hauptman Y, Schiff Y, Seger R: Mechanism of short-term ERK activation by electromagnetic fields at mobile phone frequencies. Biochem J. 2007; 405: 559-68.

11. Leszczynski D, Joenväärä $\mathrm{S}$, Reivinen J, Kuokka R: Non-thermal activation of the hsp27/p38MAPK stress pathway by mobile phone radiation in human endothelial cells: molecular mechanism for cancerand blood-brain barrier-related effects. Differentiation. 2002; 70: 120-9.

12. D'Costa H, Trueman G, Tang L, Abdel-rahman U, Abdel-rahman W, Ong K, et al.: Human brain wave activity during exposure to radiofrequency field emissions from mobile phones. Australas Phys Eng Sci Med. 2003; 26: 162-7. 
13. Kramarenko AV, Tan U: Effects of high-frequency electromagnetic fields on human EEG: a brain mapping study. Int J Neurosci. 2003; 113: 1007-19.

14. Oftedal G, Wilén J, Sandström M, Mild KH: Symptoms experienced in connection with mobile phone use. Occup Med (Lond). 2000; 50: 237-45.

15. Braune S, Wrocklage C, Raczek J, Gailus T, Lücking $\mathrm{CH}$ : Resting blood pressure increase during exposure to a radio-frequency electromagnetic field. Lancet. 1998; 351: 1857-8.

16. Röösli M, Michel G, Kuehni CE, Spoerri A: Cellular telephone use and time trends in brain tumour mortality in Switzerland from 1969 to 2002. Eur J Cancer Prev. 2007; 16: 77-82.

17. Dunson DB, Baird DD, Colombo B: Increased infertility with age in men and women. Obstet Gynecol. 2004; 103: 51-6.

18. Fejes I, Závaczki Z, Szöllosi J, Koloszár S, Daru J, Kovács L, et al.: Is there a relationship between cell phone use and semen quality? Arch Androl. 2005; 51: 385-93.

19. Wdowiak A, Wdowiak L, Wiktor H: Evaluation of the effect of using mobile phones on male fertility. Ann Agric Environ Med. 2007; 14: 169-72.

20. Agarwal A, Desai NR, Makker K, Varghese A, Mouradi R, Sabanegh E, et al.: Effects of radiofrequency electromagnetic waves (RF-EMW) from cellular phones on human ejaculated semen: an in vitro pilot study. Fertil Steril. 2009; 92: 1318-25.

21. De Iuliis GN, Newey RJ, King BV, Aitken RJ: Mobile phone radiation induces reactive oxygen species production and DNA damage in human spermatozoa in vitro. PLoS One. 2009; 4: e6446.

22. Agarwal A, Deepinder F, Sharma RK, Ranga G, Li $\mathrm{J}$ : Effect of cell phone usage on semen analysis in men attending infertility clinic: an observational study. Fertil Steril. 2008; 89: 124-8.

23. Kesari KK, Kumar S, Behari J: Mobile phone usage and male infertility in Wistar rats. Indian J Exp Biol. 2010; 48: 987-92.

24. Salama N, Kishimoto T, Kanayama HO: Effects of exposure to a mobile phone on testicular function and structure in adult rabbit. Int J Androl. 2010; 33: 88-94.

25. Aitken RJ, Bennetts LE, Sawyer D, Wiklendt AM, King BV: Impact of radio frequency electromagnetic radiation on DNA integrity in the male germline. Int J Androl. 2005; 28: 171-9.
26. Dasdag S, Zulkuf Akdag M, Aksen F, Yilmaz F, Bashan M, Mutlu Dasdag M, et al.: Whole body exposure of rats to microwaves emitted from a cell phone does not affect the testes. Bioelectromagnetics. 2003; 24: 182-8.

27. Desai NR, Kesari KK, Agarwal A: Pathophysiology of cell phone radiation: oxidative stress and carcinogenesis with focus on male reproductive system. Reprod Biol Endocrinol. 2009; 7: 114.

28. Dasdag S, Ketani MA, Akdag Z, Ersay AR, Sari I, Demirtas OC, et al.: Whole-body microwave exposure emitted by cellular phones and testicular function of rats. Urol Res. 1999; 27: 219-23.

29. Ozguner M, Koyu A, Cesur G, Ural M, Ozguner F, Gokcimen A, et al.: Biological and morphological effects on the reproductive organ of rats after exposure to electromagnetic field. Saudi Med J. 2005; 26: 405-10.

30. Saunders RD, Kowalczuk CI: Effects of $2.45 \mathrm{GHz}$ microwave radiation and heat on mouse spermatogenic epithelium. Int J Radiat Biol Relat Stud Phys Chem Med. 1981; 40: 623-32.

31. Khillare B, Behari J: Effect of Amplitude-Modulated Radiofrequency Radiation on Reproduction Pattern in Rats. Electromagn Biol Med. 1998; 17: 43-55.

32. Ribeiro EP, Rhoden EL, Horn MM, Rhoden C, Lima LP, Toniolo L: Effects of subchronic exposure to radio frequency from a conventional cellular telephone on testicular function in adult rats. J Urol. 2007; 177: 395-9.

33. Forgács Z, Somosy Z, Kubinyi G, Bakos J, Hudák A, Surján A, et al.: Effect of whole-body $1800 \mathrm{MHz}$ GSM-like microwave exposure on testicular steroidogenesis and histology in mice. Reprod Toxicol. 2006; 22: 111-7.

34. Forgács Z, Kubinyi G, Sinay G, Bakos J, Hudák A, Surján A, et al.: Effects of $1800 \mathrm{MHz}$ GSM-like exposure on the gonadal function and hematological parameters of male mice. Magy Onkol. 2005; 49: 149-51.

35. Kandeel FR, Swerdloff RS: Role of temperature in regulation of spermatogenesis and the use of heating as a method for contraception. Fertil Steril. 1988; 49: 1-23.

36. Jung A, Schill WB: Male infertility. Current life style could be responsible for infertility. MMW Fortschr Med. 2000; 142: 31-3. 
37. Varma MM, Traboulay EA Jr.: Biological effects of microwave radiation on the testes of Swiss mice. Experientia. 1975; 31: 301-2.

38. Kowalczuk CI, Saunders RD, Stapleton HR: Sperm count and sperm abnormality in male mice after exposure to $2.45 \mathrm{GHz}$ microwave radiation. Mutat Res. 1983; 122: 155-61.

39. Anderson V, Rowley J: Measurements of skin surface temperature during mobile phone use. Bioelectromagnetics. 2007; 28: 159-62.

40. Kesari KK, Kumar S, Behari J: Effects of Radiofrequency Electromagnetic Wave Exposure from Cellular Phones on the Reproductive Pattern in Male Wistar Rats. Appl Biochem Biotechnol. 2011; 15. [Epub ahead of print]

41. Agarwal A, Makker K, Sharma R: Clinical relevance of oxidative stress in male factor infertility: an update. Am J Reprod Immunol. 2008; 59: 2-11.

42. Aitken RJ, Buckingham D, Harkiss D: Use of a xanthine oxidase free radical generating system to investigate the cytotoxic effects of reactive oxygen species on human spermatozoa. J Reprod Fertil. 1993; 97: 441-50.

43. Shen HM, Chia SE, Ong CN: Evaluation of oxidative DNA damage in human sperm and its association with male infertility. J Androl. 1999; 20: 718-23.

44. Agarwal A, Saleh RA, Bedaiwy MA: Role of reactive oxygen species in the pathophysiology of human reproduction. Fertil Steril. 2003; 79: 829-43

45. Aitken RJ, Baker MA: Oxidative stress, sperm survival and fertility control. Mol Cell Endocrinol. 2006; 250: 66-9.

46. Jones R, Mann T, Sherins R: Peroxidative breakdown of phospholipids in human spermatozoa, spermicidal properties of fatty acid peroxides, and protective action of seminal plasma. Fertil Steril. 1979; 31: 531-7.

47. Grundler W, Kaiser F, Keilmann F, Walleczek J: Mechanisms of electromagnetic interaction with cellular systems. Naturwissenschaften. 1992; 79: 551-9.

48. Guney M, Ozguner F, Oral B, Karahan N, Mungan T: $900 \mathrm{MHz}$ radiofrequency-induced histopathologic changes and oxidative stress in rat endometrium: protection by vitamins $\mathrm{E}$ and $\mathrm{C}$. Toxicol Ind Health. 2007; 23: 411-20.

49. Oktem F, Ozguner F, Mollaoglu H, Koyu A, Uz E: Oxidative damage in the kidney induced by 900-MHz-emitted mobile phone: protection by melatonin. Arch Med Res. 2005; 36: 350-5.
50. Ozguner F, Bardak Y, Comlekci S: Protective effects of melatonin and caffeic acid phenethyl ester against retinal oxidative stress in long-term use of mobile phone: a comparative study. Mol Cell Biochem. 2006; 282: 83-8.

51. Balci M, Devrim E, Durak I: Effects of mobile phones on oxidant/antioxidant balance in cornea and lens of rats. Curr Eye Res. 2007; 32: 21-5.

52. Meral I, Mert H, Mert N, Deger Y, Yoruk I, Yetkin A, et al.: Effects of 900-MHz electromagnetic field emitted from cellular phone on brain oxidative stress and some vitamin levels of guinea pigs. Brain Res. 2007; 1169: 120-4.

53. Koppers AJ, De Iuliis GN, Finnie JM, McLaughlin EA, Aitken RJ: Significance of mitochondrial reactive oxygen species in the generation of oxidative stress in spermatozoa. J Clin Endocrinol Metab. 2008; 93: 3199-207.

54. Falzone N, Huyser C, Franken DR, Leszczynski D: Mobile phone radiation does not induce pro-apoptosis effects in human spermatozoa. Radiat Res. 2010; 174: 169-76.

55. Kumar S, Kesari KK, Behari J: Influence of microwave exposure on fertility of male rats. Fertil Steril. 2011; 95: 1500-2.

56. Kumar S, Kesari KK, Behari J: Evaluation of genotoxic effects in male Wistar rats following microwave exposure. Indian J Exp Biol. 2010; 48: 586-92.

57. Moustafa YM, Moustafa RM, Belacy A, Abou-El-Ela $\mathrm{SH}$, Ali FM: Effects of acute exposure to the radiofrequency fields of cellular phones on plasma lipid peroxide and antioxidase activities in human erythrocytes. J Pharm Biomed Anal. 2001; 26: 605-8.

58. Oral B, Guney M, Ozguner F, Karahan N, Mungan T, Comlekci S, et al.: Endometrial apoptosis induced by a $900-\mathrm{MHz}$ mobile phone: preventive effects of vitamins E and C. Adv Ther. 2006; 23: 957-73.

59. Alvarez JG, Touchstone JC, Blasco L, Storey BT: Spontaneous lipid peroxidation and production of hydrogen peroxide and superoxide in human spermatozoa. Superoxide dismutase as major enzyme protectant against oxygen toxicity. J Androl. 1987; 8: 338-48.

60. Burch JB, Reif JS, Noonan CW, Ichinose T, Bachand AM, Koleber TL, et al.: Melatonin metabolite excretion among cellular telephone users. Int J Radiat Biol. 2002; 78: 1029-36.

61. Gavella M, Lipovac V: Antioxidative effect of melatonin on human spermatozoa. Arch Androl. 2000; 44: $23-7$. 
62. Ha BY: Stabilization and destabilization of cell membranes by multivalent ions. Phys Rev E Stat Nonlin Soft Matter Phys. 2001; 64: 051902.

63. Lew VL, Hockaday A, Freeman CJ, Bookchin RM: Mechanism of spontaneous inside-out vesiculation of red cell membranes. J Cell Biol. 1988; 106: 1893 901.

64. Steck TL, Weinstein RS, Straus JH, Wallach DF: Inside-out red cell membrane vesicles: preparation and purification. Science. 1970; 168: 255-7.

65. Bawin SM, Kaczmarek LK, Adey WR: Effects of modulated VHF fields on the central nervous system. Ann N Y Acad Sci. 1975; 247: 74-81.

66. Blackman CF, Benane SG, House DE, Elliott DJ: Importance of alignment between local DC magnetic field and an oscillating magnetic field in responses of brain tissue in vitro and in vivo. Bioelectromagnetics. 1990; 11: 159-67.

67. Blackman CF, Benane SG, Kinney LS, Joines WT, House DE: Effects of ELF fields on calcium-ion efflux from brain tissue in vitro. Radiat Res. 1982; 92: 510-20.

68. Goldsworthy A: The Biological Effects of Weak Electromagnetic Fields. [Homepage on the Internet]. 2007 [cited 2011 Feb 11]. Available from: Web site: http://www.hese-project.org/hese-uk/en/papers/ goldsworthy_bio_weak_em_07.pdf

69. Prien SD, Lox CD, Messer RH, DeLeon FD: Seminal concentssrations of total and ionized calcium from men with normal and decreased motility. Fertil Steril. 1990; 54: 171-2.

70. Hong CY, Chiang BN, Turner P: Calcium ion is the key regulator of human sperm function. Lancet. 1984; 2: 1449-51.

71. Kiliç S, Sarica K, Yaman O, Soygür T, Gögüs O, Yaman LS: Effect of total and ionized calcium levels of seminal fluid on sperm motility. Urol Int. 1996; 56: 215-8.

72. Alavi SM, Cosson J: Sperm motility in fishes. (II) Effects of ions and osmolality: a review. Cell Biol Int. 2006; 30: 1-14.

73. Larsson C: New insights into PKC family affairs: three novel phosphorylation sites in PKCepsilon and at least one is regulated by PKCalpha. Biochem J. 2008; 411: e15-6.

74. Kimura K, Katoh N, Sakurada K, Kubo S: Phospholipid-sensitive $\mathrm{Ca} 2+$-dependent protein kinase system in testis: localization and endogenous substrates. Endocrinology. 1984; 115: 2391-9.
75. Naor Z, Breitbart H: Protein kinase C and mammalian spermatozoa acrosome reaction. Trends Endocrinol Metab. 1997; 8: 337-42.

76. Nishizuka Y: Studies and perspectives of protein kinase C. Science. 1986; 233: 305-12.

77. Nikula H, Naor Z, Parvinen M, Huhtaniemi I: Distribution and activation of protein kinase $\mathrm{C}$ in the rat testis tissue. Mol Cell Endocrinol. 1987; 49: 39-49.

78. Rotem R, Paz GF, Homonnai ZT, Kalina M, Naor Z: Further studies on the involvement of protein kinase $\mathrm{C}$ in human sperm flagellar motility. Endocrinology. 1990; 127: 2571-7.

79. Rotem R, Paz GF, Homonnai ZT, Kalina M, Naor Z: Protein kinase $\mathrm{C}$ is present in human sperm: possible role in flagellar motility. Proc Natl Acad Sci U S A. 1990; 87: 7305-8.

80. Agarwal A, Deepinder F, Sharma RK, Ranga G, Li J: Effect of cell phone usage on semen analysis in men attending infertility clinic: an observational study. Fertil Steril. 2008; 89: 124-8.

81. Blank M, Goodman R: Electromagnetic fields may act directly on DNA. J Cell Biochem. 1999; 75: 369-74.

82. Dunphy WG, Brizuela L, Beach D, Newport J: The Xenopus cdc2 protein is a component of MPF, a cytoplasmic regulator of mitosis. Cell. 1988; 54: 423-31.

83. Gautier J, Norbury C, Lohka M, Nurse P, Maller J: Purified maturation-promoting factor contains the product of a Xenopus homolog of the fission yeast cell cycle control gene cdc2+. Cell. 1988; 54: 433-9.

84. Moon K, Shin HJ, Ahn H, Kim J, Shin S, Yun S, et al.: Long-Term Exposure of Rats to $2.45 \mathrm{GHz}$ Electromagnetic Field: Effects on Reproductive Function, in: Magjarevic R, Nagel JH (editors): World Congress on Medical Physics and Biomedical Engineering, IFMBE Proceedings 2006, Springer Berlin Heidelberg, 14(4): 2767-9.

85. Kesari KKB: J. Effects of microwave at $2.45 \mathrm{GHz}$ radiations on reproductive system of male rats. Toxicological \& Environmental Chemistry. 2010; 92: 1135-47.

86. Kesari KK, Behari J: Microwave exposure affecting reproductive system in male rats. Appl Biochem Biotechnol. 2010; 162: 416-28.

87. Cayli S, Sakkas D, Vigue L, Demir R, Huszar G: Cellular maturity and apoptosis in human sperm: creatine kinase, caspase-3 and Bcl-XL levels in mature and diminished maturity sperm. Mol Hum Reprod. 2004; 10: 365-72. 
88. Ceruti S, Beltrami E, Matarrese P, Mazzola A, Cattabeni F, Malorni W, et al.: A key role for caspase- 2 and caspase-3 in the apoptosis induced by 2-chloro-2'-deoxyadenosine (cladribine) and 2-chloro-adenosine in human astrocytoma cells. Mol Pharmacol. 2003; 63: 1437-47.

89. Riedl SJ, Shi Y: Molecular mechanisms of caspase regulation during apoptosis. Nat Rev Mol Cell Biol. 2004; 5: 897-907.

90. Pommier Y, Sordet O, Antony S, Hayward RL, Kohn KW: Apoptosis defects and chemotherapy resistance: molecular interaction maps and networks. Oncogene. 2004; 23: 2934-49.

91. Spierings D, McStay G, Saleh M, Bender C, Chipuk J, Maurer U, et al.: Connected to death: the (unexpurgated) mitochondrial pathway of apoptosis. Science. 2005; 310: 66-7.

92. Lee JS, Ahn SS, Jung KC, Kim YW, Lee SK: Effects of $60 \mathrm{~Hz}$ electromagnetic field exposure on testicular germ cell apoptosis in mice. Asian J Androl. 2004; 6: 29-34.

93. Leszczynski D, Nylund R, Joenväärä S, Reivinen J: Applicability of discovery science approach to determine biological effects of mobile phone radiation. Proteomics. 2004; 4: 426-31.

94. Lai H, Singh NP: Single- and double-strand DNA breaks in rat brain cells after acute exposure to radiofrequency electromagnetic radiation. Int J Radiat Biol. 1996; 69: 513-21.

95. Garaj-Vrhovac V, Horvat D, Koren Z: The effect of microwave radiation on the cell genome. Mutat Res. 1990; 243: 87-93.

96. Maes A, Verschaeve L, Arroyo A, De Wagter C, Vercruyssen L: In vitro cytogenetic effects of 2450 $\mathrm{MHz}$ waves on human peripheral blood lymphocytes. Bioelectromagnetics. 1993; 14: 495-501.

97. Sarkar S, Ali S, Behari J: Effect of low power microwave on the mouse genome: a direct DNA analysis. Mutat Res. 1994; 320: 141-7.

98. Belyaev IY, Koch CB, Terenius O, RoxströmLindquist K, Malmgren LO, H Sommer W, et al.: Exposure of rat brain to $915 \mathrm{MHz}$ GSM microwaves induces changes in gene expression but not double stranded DNA breaks or effects on chromatin conformation. Bioelectromagnetics. 2006; 27: 295-306.

99. Criswell KA, Krishna G, Zielinski D, Urda GA, Theiss JC, Juneau P, et al.: Use of acridine orange in: flow cytometric assessment of micronuclei induction. Mutat Res. 1998; 414: 63-75.
100.Gollapudi BB, McFadden LG: Sample size for the estimation of polychromatic to normochromatic erythrocyte ratio in the bone marrow micronucleus test. Mutat Res. 1995; 347: 97-9.

101.Wang SM, Wang DW, Peng RY, Gao YB, Yang Y, $\mathrm{Hu} \mathrm{WH}$, et al.: Effect of electromagnetic pulse irradiation on structure and function of Leydig cells in mice. Zhonghua Nan Ke Xue. 2003; 9: 327-30.

102. Zhou W, Wang XB, Yang JQ, Liu Y, Zhang GB: Influence of electromagnetic irradiation on P450scc mRNA expression in rat testis tissues and protective effect of the shield. Zhonghua Nan Ke Xue. 2005; 11: 269-71.

103. Salama N, Kishimoto T, Kanayama HO, Kagawa S: The mobile phone decreases fructose but not citrate in rabbit semen: a longitudinal study. Syst Biol Reprod Med. 2009; 55: 181-7.

104.de Seze R, Fabbro-Peray P, Miro L: GSM radiocellular telephones do not disturb the secretion of antepituitary hormones in humans. Bioelectromagnetics. 1998; 19: 271-8.

105.Djeridane Y, Touitou Y, de Seze R: Influence of electromagnetic fields emitted by GSM-900 cellular telephones on the circadian patterns of gonadal, adrenal and pituitary hormones in men. Radiat Res. 2008; 169: 337-43.

106.Bortkiewicz A: A study on the biological effects of exposure mobile-phone frequency EMF. Med Pr. 2001; 52: 101-6.

107.Fang HH, Zeng GY, Nie Q, Kang JB, Ren DQ, Zhou JX, et al.: Effects on structure and secretion of pituitary gland in rats after electromagnetic pulse exposure. Zhonghua Yi Xue Za Zhi. 2010; 90: 3231-4.

108. Mouradi RD, Nisarg; Erdemir, Ahmet; Agarwal, Ashok: The Use of FDTD in establishing In-vitro experimentation conditions representative of lifelike cell phone radiation on the spermatozoa. 2011 (Unpublished observation).

109.Administration USFaD. Cell Phones: RadiationEmitting Products. Research. 2010; Available from: http://www.fda.gov/Radiation-EmittingProducts/ RadiationEmittingProductsandProcedures/HomeBusinessandEntertainment/CellPhones/default.htm

110.Lee NG, Kent. Cell phone radiation levels. 2010; Available from: http://reviews.cnet.com/cell-phoneradiation-levels $/ ?$ tag $=r b \_c o n t e n t \% 3 b r b \_m t x$

111.Kesari KK, Kumar S, Behari J: Mobile phone usage and male infertility in Wistar rats. Indian J Exp Biol. 2010; 48: 987-92. 
112.De Iuliis GN, Newey RJ, King BV, Aitken RJ: Mobile phone radiation induces reactive oxygen species production and DNA damage in human spermatozoa in vitro. PLoS One. 2009; 4: e6446.

113.Yan JG, Agresti M, Bruce T, Yan YH, Granlund A, Matloub HS: Effects of cellular phone emissions on sperm motility in rats. Fertil Steril. 2007; 88: 957-64.
114.Erogul O, Oztas E, Yildirim I, Kir T, Aydur E, Komesli G, et al.: Effects of electromagnetic radiation from a cellular phone on human sperm motility: an in vitro study. Arch Med Res. 2006; 37: 840-3.

115.Makker K, Varghese A, Desai NR, Mouradi R, Agarwal A: Cell phones: modern man's nemesis? Reprod Biomed Online. 2009; 18: 148-57.

Submitted for publication: February 21, 2011

Correspondence address:

Dr. Ashok Agarwal

Professor, Lerner College of Medicine

Accepted after revision:

Director, Andrology Laboratory

Director, Center for Reproductive Medicine

Cleveland Clinic, Desk A19.1

9500 Euclid Avenue

Cleveland, Ohio 44195, United States

E-mail: agarwaa@ccf.org 